\title{
Analysis of The Needs of Karanganyar Traditional Children Toys Production Machine, Welahan, Jepara
}

\author{
Imaniar Purbasari, Jayanti Putri Purwaningrum, Hutomo Rusdianto \\ \{imaniar.purbasari@umk.ac.id ${ }^{1}$,jayanti.putri@umk.ac.id ${ }^{2}$, hutomo.rusdianto@umk.ac.id ${ }^{3}$ \} \\ Universitas Muria Kudus ${ }^{123}$
}

\begin{abstract}
The form of the superior products in the Karanganyar village in Jepara, traditional toys, klothokan and kitiran still survives amid high-tech toys. The community as an element of production still faithfully applies their energy and skills to express ideas and creations of simple children's toys. The complexity and detail of traditional children's toys is a major factor in the culture of production with human hands. The need for modern technology machines such as sponge molding machines in klothokan toys, bamboo oven drying machines and bamboo lathes in kitiaran toys is a technological innovation requirement that must be introduced and familiarized when the production process is carried out by the community. The expected result is that the amount of goods produced increases without bothering human labor and natural factors such as weather are no longer a constraint for the community to produce superior quality products.
\end{abstract}

Keywords: traditional, educational games, children.

\section{Introduction}

Indonesia's creative industry, which has a variety of features, makes our country rich in regional cultural products. One of the creative industries in Indonesia that supports the introduction of regional culture, namely the children's toy industry. The local culture-based children's toys industry is the result of the creation of society towards children's play needs and complementary games that have been created by ancestors. Therefore playing is attached to social groups that are applied through symbolic interaction in the form of traditional games.

Playing is one of the ways children learn about their environment through senses. The feeling generated from playing activities is usually in the form of pleasant responses obtained from the social environment. Playing will foster interest in exploring children, practicing physical growth, and sharpening imagination, as well as giving experience to interact with the social environment. The form of social support for children's growth and development can be demonstrated by the creation of games that adjust the environment in which they live. So playing is a tradition that has been entrenched in children's social life in society.

Playing is an activity with practical value as a children's media to develop certain abilities in children (Sujiono, 2005) [1]. The characteristics of play are active and fun activities carried out voluntarily and internal motivation arises from within the child itself. Isniwarti (2010:8) [2], mentions the impact of playing on children: (1) Playing while learning, (2) Supporting physical development and mental health, (3) Training children tested in the face of challenges and culture. Meanwhile, according to Mutiah (2010: 113) [3] suggests that the game is able to 
stimulate children's growth: (1) As a means of fostering socialization skills in children, (2) Developing children's potential and abilities, (3) Means of developing children's emotions.

But the main thing to play has a positive impact, among others: (a) optimizing the physical and mental development of children, (b) meeting children's emotional needs, (c) developing children's creativity and language skills, (d) helping the socialization process, (e) developing abilities motoric, cognitive, affective, language and social aspects (Suyanto, 2005). The social role of the playing aspect is the impact of the creation of various types of games that have been created.

The term "game" comes from the basic word "play" which means doing fun. Traditional games or folk games are a type of game that grows and develops in the past, especially in rural areas. Traditional games usually develop due to the needs of the surrounding community. Traditional games are also influenced by the nature of the surrounding environment which is interesting and entertaining according to the conditions of today's society. Traditional games are generally recreational, because many require children's creation (Yunus, 1981) [4]. The game reconstructs various social activities in society. The influence of the natural environment and culture of society changes both in the form of substitution, change, addition or reduction by adjusting the needs of the local community. So the naming of traditional games differs between regions but usually has similarities or similarities in the procedures and equipment of the game.

Classification of play according to Mildred Parten (1932) seen from the social development of children, includes: (1) Solitary games (playing alone), (2) Onlooker games (playing by seeing friends playing), (3) Parallel games (playing parallel with friends with the same material but working alone), (4) Associative games, (5) Cooperative games (playing with rules and division of roles). Games based on how to play can be grouped into: (a) physical play, (b) games with children's songs, (c) puzzles, mathematical logical thinking, (d) playing with objects, (e) role playing.

This type of game can be classified in children's play with the child's game conditions must have identification: (1) must be happy for the child, (2) must provide opportunities for children to fantasize, (3) should contain elements of beauty or artistic value, (4) must contain the value of education for children in terms of order, discipline, sportsmanship and togetherness.

Besides that, traditional games contain cultural values in traditional games children can be classified into several positive values:

a. The value of pleasure or excitement, the nature of the child uses play to create joy

b. The value of freedom, playing freely in the open environment raises a positive attitude free from pressure

c. The value of friendship, playing requires partners so as to train children's social life skills.

d. The value of democracy, in playing it requires openness, honesty, fairness and mutual respect for each other

e. The value of leadership, in the group game can be coordinated by a leader

f. The value of responsibility for each game encourages the player to win the game so that the child has responsibility for the course of the game

g. The value of togetherness and mutual help, in the game the group is not only one who can play a role but the effort to cooperate is a step towards group victory

h. The value of compliance, existing game rules determine game winnings

i. The value of mathematical skills, each player must be able to count 
j. The value of thinking skills, playing requires thinking tactics in completing the game.

$\mathrm{k}$. The value of honesty and sportsmanship, in play is needed to give firmness in playing

The development of traditional games in the modern era is being promoted in Indonesia. Various types of individual and group games that are being abandoned with technology-based games are now being attempted to be revived. One of the efforts to reinvigorate traditional games is to package game facilities and infrastructure to become more modern.

One of the efforts to modernize traditional games through attractive technology and packaging. Examples of the types of traditional game infrastructure facilities that will be developed in a modern way are taken from the children's toy centers in the Karanganyar village, Welahan, Jepara. To support the modernization of traditional games can be developed to attract children's interest by applying (1) simple natural ingredients as a basis for traditional game equipment, (2) the technology of traditional game machine production equipment, and (3) packaging of children's toy sales with a modern design. The success of modification of infrastructure facilities supporting traditional games with modern machines will improve the quality management and management of traditional children's toys by local craftsmen.

\section{Method}

The problem in the traditional children's toy Kratif industry is that researchers find business partners as well as toy crafters in Karanganyar, Welahan, Jepara. The method applied to the three main aspects of the difficulty of craftsmen, includes.

a. Raw materials for traditional children's toys still use synthetic and chemical materials that are not child friendly because they are pursuing target markets at low prices. Therefore, a method of assistance is needed to find alternative raw materials that utilize the surrounding environment and do not cause harm to be played by children. The methods that can be used through observation and literature studies on natural raw materials that have a level of security and resistance to the production of traditional children's toys

b. The production of children's toys as one of the creative industries should be able to utilize creativity or specific cultural-based skills so as not to eliminate the role of the community as inventors and business implementers. The introduction of machine technology or production aids is trying to be implemented by designing the replacement needs of human power to accelerate and increase the amount of production. In addition, control of the quality of goods becomes more standardized

c. The product design process is well conceptualized and not only follows market demand, must have a safe, attractive, educative and environment-based function. The creation of labels and the provision of knowledge of products is an identity as well as education of traditional children's toys that we seldom find in toys at low prices:

1) Brainstorming about product design development that has been developed.

2) Assistance in knowledge of children's toy designs that have educational values.

3) Packaging is mainly the packaging of traditional children's toys which have not yet become production costs 


\section{Result and Discussion}

The problems that occur in the traditional children's toys creative industry in the Jepara region result in changes in processes and production, including:

\subsection{Analysis of Production Machine Needs}

The raw materials for making traditional children's toys include: children's toys lelean or trothokan made of sponge foam material, cement, sand, rubber, glue, wire, paint and plastic are difficult materials to get the predicate SNI children toys. The production process with manual sponge printing equipment causes the limited number of sponge prints that rely on human power. The selling price of Rp 1500, - up to Rp 5000, - is a price that is not optimal if all components of a child's toy are done with human power. At the same time, the product does not have a good trade label, so it is difficult to introduce and even give recognition to products that are commodities of a region.

Identification of technology production equipment or machines is expected to be able to process raw materials into toy products that have security for children who use products. The criteria for good product raw materials and technology need:

Table 1. Identification of the Sponge Printing Machine.

\begin{tabular}{llllll}
\hline No & Material Name & Item Name & Danger & Subtitute Proposal & Machine Needed \\
\hline 1 & Sponge & Sponge & Plant waste & Sponge & $\begin{array}{l}\text { Sponge Cutting } \\
\text { Blade } \\
\text { Compressor }\end{array}$ \\
2 & Sponge paint & Sponge paint & $\begin{array}{l}\text { Smells unpleasant } \\
\text { and imprints on } \\
\text { the fingers }\end{array}$ & Paint water base & $\begin{array}{l}\text { Paint Poster and } \\
\text { Clear Pilox }\end{array}$ \\
3 & $\begin{array}{l}\text { Screen Printing } \\
\text { Paint }\end{array}$ & catfish tail & Easy to tear & Screen Printing Paint & $\begin{array}{l}\text { Screen Printing } \\
\text { Machine }\end{array}$ \\
& Wire & Hook wire & Sharp & Hose coating & $\begin{array}{l}\text { Wire Cutting } \\
\text { Tools in large } \\
\text { quantities } \\
\text { Wood Lathes }\end{array}$ \\
& $\begin{array}{l}\text { Cement and } \\
\text { Sand } \\
\text { Rubber bracelet }\end{array}$ & Binder & Less safe & Food rubber & - \\
\hline
\end{tabular}

\subsection{The Technology of Sponge Printing Machine in The Traditional Toy Industry}

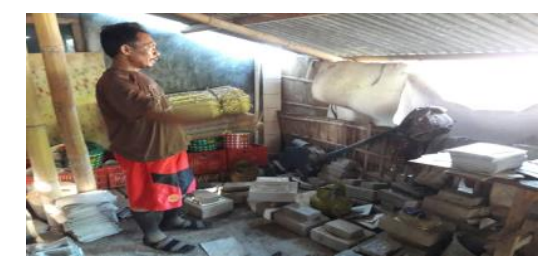

Source: Researcher's Personal Documentation

Fig. 1. Simple technology with human power. 
Based on the results of observation and analysis of the needs of production equipment partners, they still use human power and depend on weather so that another equipment is needed for production effectiveness. The production process that still uses manual machines identified the type of product still follows the creation of craftsmen. And is influenced by the local coastal environment, so that the amount of production adjusts the ability or labor force, and has not had a good standard of toy quality for the traditional toy category. Therefore, it is necessary to design a traditional children's toy sponge printer using heat energy and a sponge press machine. The engine design needed by the craftsmen is as follows.

Table 2. Sponge Printer Machine Specifications.

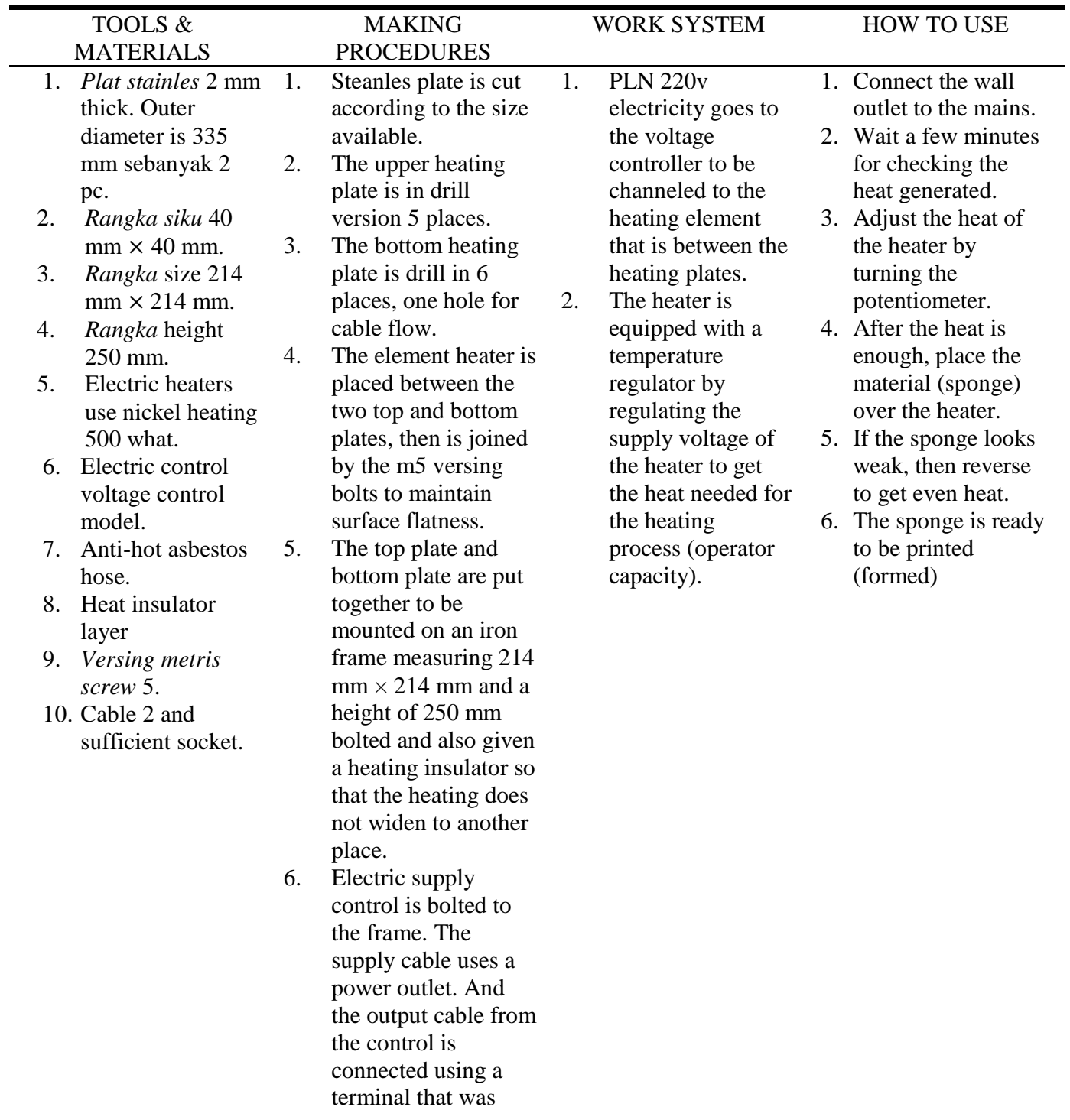


previously installed

with a heat-resistant

sleeve (asbestos

hose)

\begin{tabular}{|c|c|c|c|}
\hline $\begin{array}{c}\text { TOOLS \& } \\
\text { MATERIALS }\end{array}$ & $\begin{array}{c}\text { MAKING } \\
\text { PROCEDURES }\end{array}$ & WORK SYSTEM & HOW TO USE \\
\hline $\begin{array}{l}\text { 1. Mold (Dies / } \\
\text { Molding) a set of } \\
\text { top-downs. } \\
\text { 2. Rangka siku iron } \\
\text { size } 50 \mathrm{~mm} \times 50 \\
\text { mm. } \\
\text { 3. The bottom iron } \\
\text { plate is } 300 \mathrm{~mm} \times \\
400 \mathrm{~mm} \text { thick and } \\
8 / 10 \mathrm{~mm} \text { thick. } \\
\text { 4. Placemat iron plate } \\
\text { over } 300 \mathrm{~mm} \times 300 \\
\text { mm and } 8 / 10 \mathrm{~mm} \\
\text { thick. } \\
\text { 5. The pressure plate is } \\
300 \mathrm{~mm} \times 300 \mathrm{~mm} \\
\text { thick and } 8 / 10 \mathrm{~mm} \\
\text { thick. } \\
\text { 6. Spring suppresses } \\
\text { outer diameter } 16 \\
\text { mm, length } 30 \mathrm{~mm} \\
\text { as much as } 4 \text { pieces. } \\
\text { M8 bolts } 60 \mathrm{~mm} \\
\text { long as many as } 4 \\
\text { pieces. } \\
\text { 8. The curling as are } \\
12 \text { mm long by } 500 \\
\text { mm. } \\
\text { 9. Eccentric Cam } \\
\text { diameter } 140 \mathrm{~mm} \\
\text { thick } 40 \mathrm{~mm} \text {. } \\
\text { 10. Eccentric as } \\
\text { diameter } 20 \mathrm{~mm} \\
\text { long } 500 \mathrm{~mm} \text { long. } \\
\text { 11. Pressing as } 25 \mathrm{~mm} \\
\times 300 \mathrm{~mm} \text {. } \\
\text { 12. } 6201 \text { number press } \\
\text { bearing as much as } \\
1 \text { piece. } \\
\text { 13. Press bearing as } \\
\text { diameter } 40 \mathrm{~mm} \\
\text { length } 70 \mathrm{~mm} \text { as } \\
\text { much as } 1 \text { piece. } \\
\text { 14. Press bearing baut }\end{array}$ & $\begin{array}{l}\text { 1. The main frame bolts } \\
\text { are } 300 \text { mm } \times 300 \\
\text { mm with a height of } \\
150 \text { mm } \\
\text { 2. The bottom plate } \\
\text { plate on the bur tap is } \\
\text { m6 for the daes } \\
\text { binding site (bottom } \\
\text { mold). } \\
\text { 3. Upper plate plate in } \\
\text { m6 bur tap for daes } \\
\text { bonding (upper } \\
\text { mold), } 4 \text { tap bur for } \\
\text { spring seat plate } \\
\text { 4he pressure plate in } \\
\text { the bur with a } \\
\text { diameter of } 9 \text { mm is } 4 \\
\text { places as a spring } \\
\text { bolt, then in the } 8 \text { mm } \\
\text { diameter bur center } \\
\text { for the holder of the } \\
\text { pressing axle, bur tap } \\
\text { m10 for a pressure } \\
\text { guide so that the drop } \\
\text { can be straight } \\
\text { (center). } \\
\text { 5. The press with both } \\
\text { ends is buried with a } \\
\text { m8 tap as deep as } 30 \\
\text { mm. } \\
\text { 6. Diembling pressing } \\
\text { force with pressure } \\
\text { plate and pressure } \\
\text { bearing holder by } \\
\text { means of m8 bolt. } \\
\text { 7. The eccentric axles } \\
\text { are attached to the } \\
\text { side frame that has } \\
\text { been installed in the } \\
\text { pillow block. } \\
\text { 8. As crank is installed. } \\
\text { 9. The guide stand } \\
\text { frame is attached to } \\
\text { the right and left side }\end{array}$ & $\begin{array}{l}\text { 1. The pressure } \\
\text { works to put } \\
\text { pressure down on } \\
\text { the printer. } \\
\text { 2. With this pressure, } \\
\text { causing the holder } \\
\text { per pressure to be } \\
\text { pressed down so as } \\
\text { to give a stronger } \\
\text { pressure effect. } \\
\text { 3. The pressure on } \\
\text { the pressure } \\
\text { suppressor gives } \\
\text { pressure to the top } \\
\text { mold to the bottom } \\
\text { mold. } \\
\text { 4. By pulling the } \\
\text { pressure lever to } \\
\text { the maximum, the } \\
\text { lever can be } \\
\text { locked } \\
\text { automatically so } \\
\text { that the user does } \\
\text { not need to press } \\
\text { simultaneously } \\
\text { until the cooling of } \\
\text { the sponge occurs. } \\
\text { The provision of a } \\
\text { press shaft guide } \\
\text { serves to express } \\
\text { the direction of } \\
\text { rise and fall of the } \\
\text { mold, so that the } \\
\text { mold is not } \\
\text { dislocated }\end{array}$ & $\begin{array}{l}\text { 1. Prepare a heated } \\
\text { sponge for printing. } \\
\text { 2. Enter the sponge } \\
\text { between the top and } \\
\text { bottom printers. } \\
\text { 3. Make the sponge } \\
\text { symmetrical and } \\
\text { precise between the } \\
\text { top mold and the } \\
\text { bottom mold. } \\
\text { 4. Pull the pressure } \\
\text { lever until the } \\
\text { pressure is locked. } \\
\text { 5. Let stand for a while } \\
\text { until the sponge } \\
\text { reaches normal } \\
\text { temperature. } \\
\text { 6. After the sponge is } \\
\text { felt to have returned } \\
\text { to normal } \\
\text { temperature, lift the } \\
\text { pressure lever. } \\
\text { 7. Take the molded } \\
\text { sponge that has been } \\
\text { formed. } \\
\text { 8. The printed sponge } \\
\text { is ready for use. }\end{array}$ \\
\hline
\end{tabular}




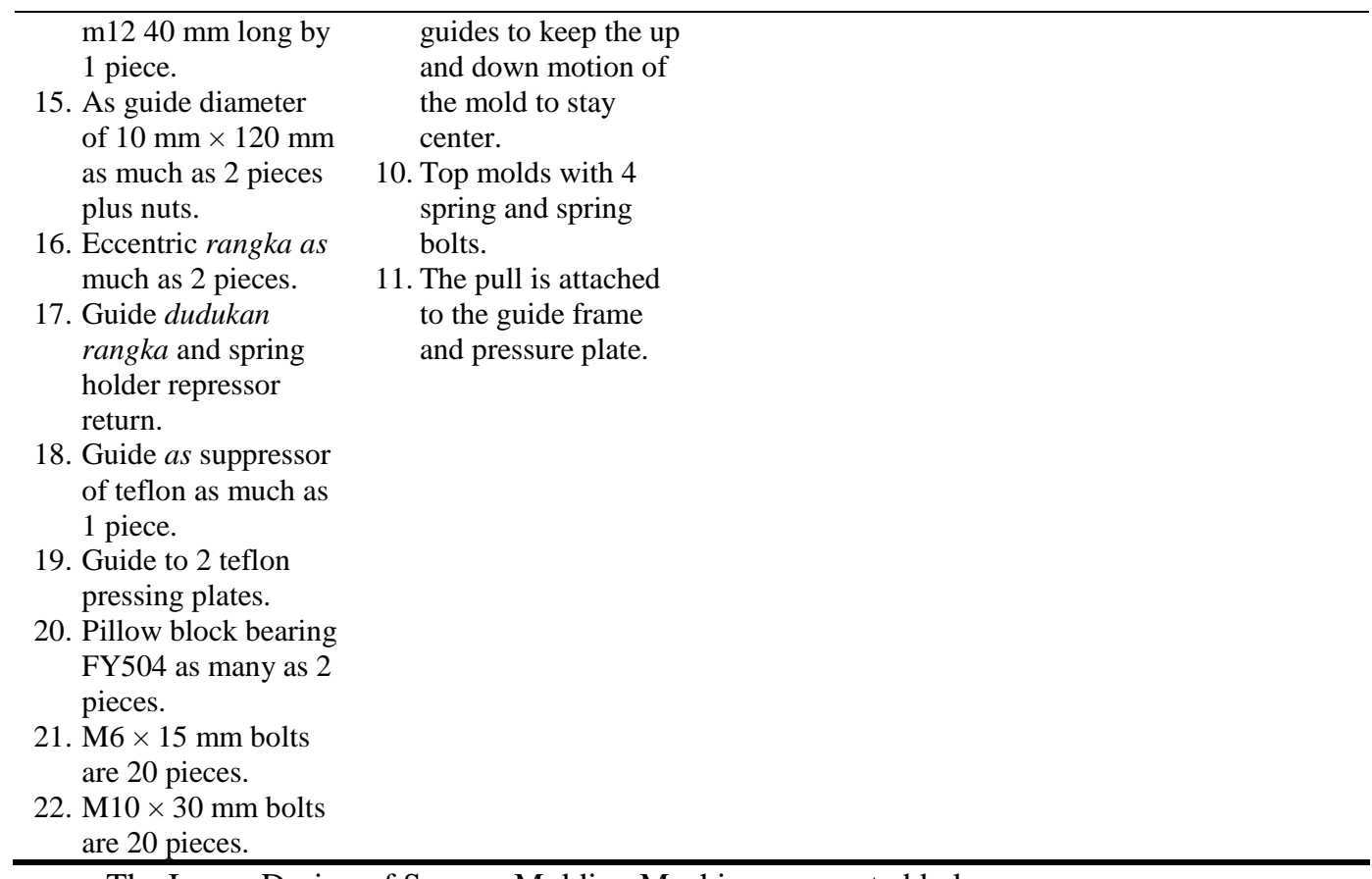
The Image Design of Sponge Molding Machines presented below:

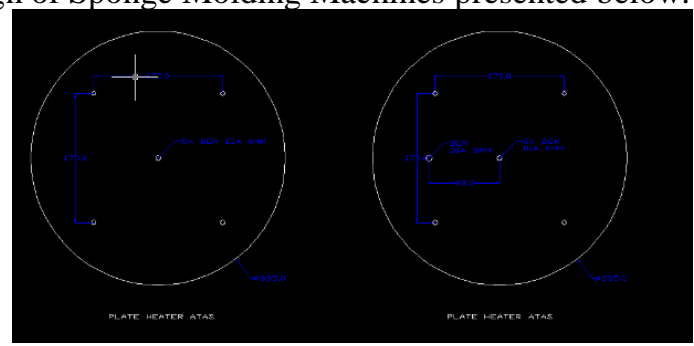

Fig. 2. Heating table.

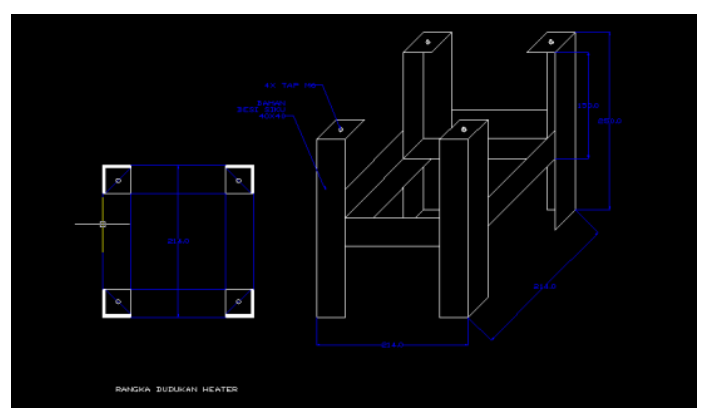

Fig. 3. Heater Table Legs. 


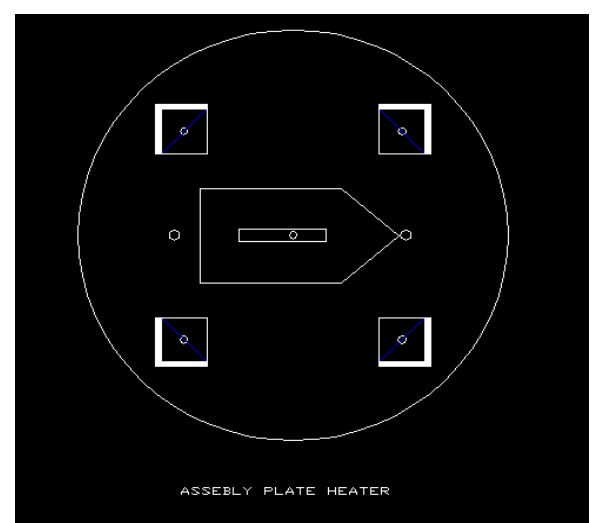

Fig. 4. Sponge Printer Table

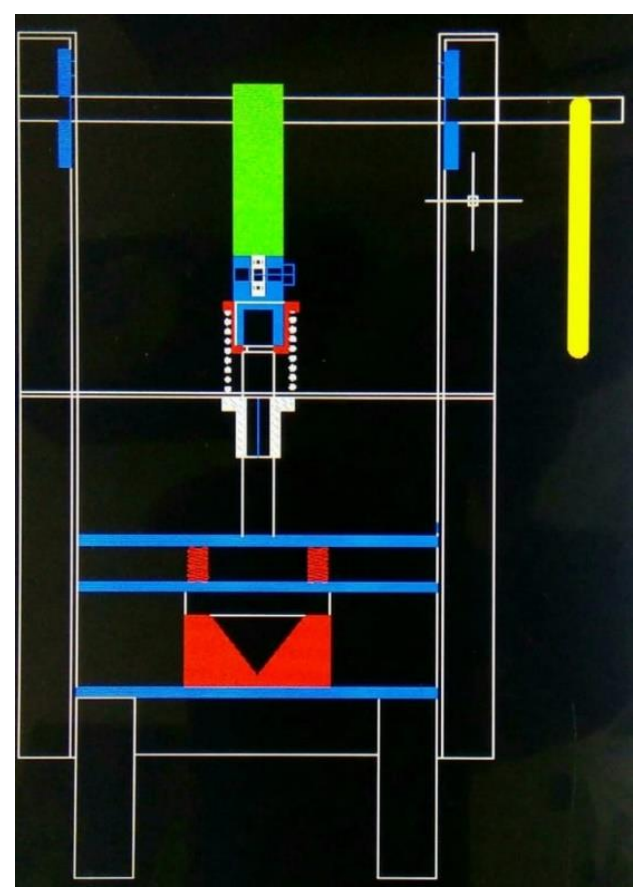

Fig. 5. Catfish Printing Machine. 


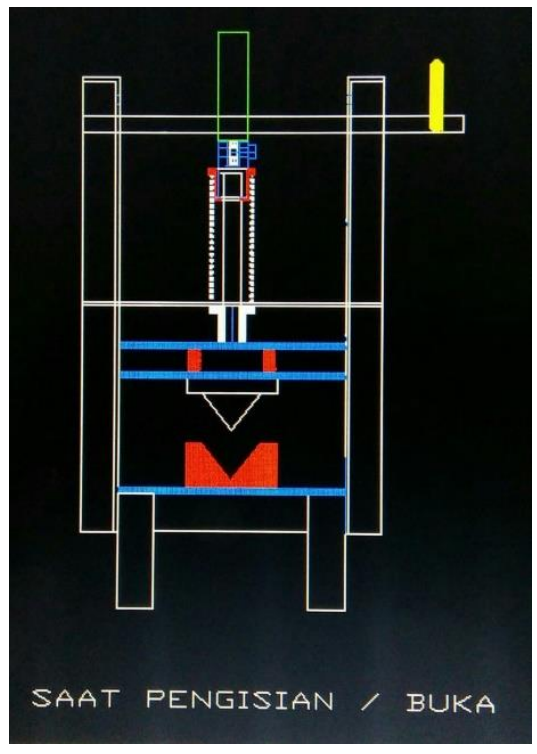

Fig. 6. Before Use.

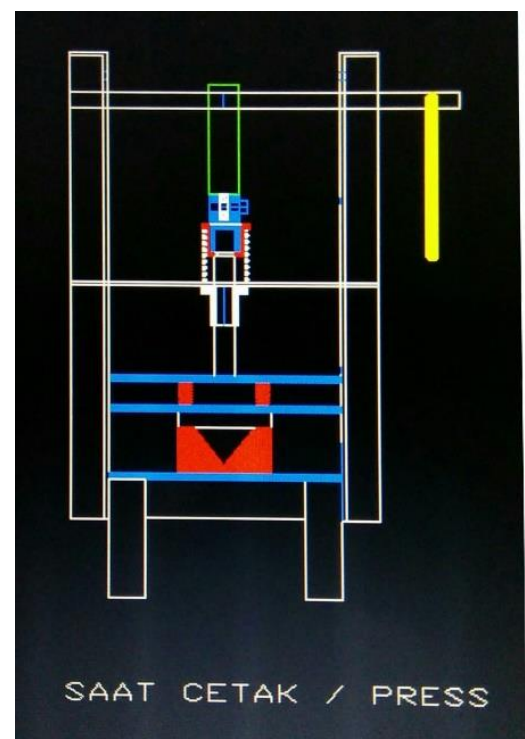

Fig. 7. After Use. 


\subsection{Packaging children's toys with modern designs}

The packaging that has been done by entrepreneurs as well as traditional children's toy crafters from Karanganyar Welahan Jepara is only in the form of clear white plastic without labels and is tightened with ropes. There is no information in the brand of products sold. Continuity of product marketing is neglected, so it is not known where and by whom the product was developed.

The important of packaging on products using designs that children like to use IT technology is needed. Verbal information in the form of images and writings written in packaging tries to be presented. The importance of this information makes the child toy consumers know, remember and disseminate product information (Irrubai, 2016) [5].

\section{Acknowledgments}

The success of the preparation of the results of the analysis of the needs of Karanganyar, Welahan, Jepara traditional children's toy production machines is the support of various parties. Acknowledgments the authors convey to The Ministry of Research Technology and Higher Education, Muria Kudus University, and the Karanganyar Village , Welahan Jepara.

\section{References}

[1] Sujiono, Forming Children's Intelligence from Early Age. Jogyakarta: Jogyakarta: Think, 2005.

[2] Isniwarti, "TherapyValues for Engklek Traditional Games for the Primary School Age Children," Publication manuscript. 2010.

[3] Mutiah, Psychology of Early Childhood Play. Jakarta: Kencana: Jakarta, 2010.

[4] Y. Ahman, "The People's Game of the Special Region of Yogyakarta," Yogyakarta: Ministry of Education and Culture Proyak Inventory and Documentation of Regional Culture. 1981.

[5] M. L. Irrubai, "Strategic Labeling, Packaging, and Marketing of Home Industry Products," Sociodidactika Soc. Sci. Educ. J., vol. 3, pp. 17-26, 2016. 